\title{
Mutations Causing Liddle Syndrome Reduce Sodium-dependent Downregulation of the Epithelial Sodium Channel in the Xenopus Oocyte Expression System
}

\author{
Stephan Kellenberger, Ivan Gautschi, Bernard C. Rossier, and Laurent Schild \\ Institut de Pharmacologie et de Toxicologie, Université de Lausanne, 1005 Lausanne, Switzerland
}

\begin{abstract}
Liddle syndrome is an autosomal dominant form of hypertension resulting from deletion or missense mutations of a PPPxY motif in the cytoplasmic $\mathrm{COOH}$ terminus of either the $\beta$ or $\gamma$ subunit of the epithelial $\mathrm{Na}$ channel (ENaC). These mutations lead to increased channel activity. In this study we show that wild-type $\mathrm{ENaC}$ is downregulated by intracellular $\mathrm{Na}^{+}$, and that Liddle mutants decrease the channel sensitivity to inhibition by intracellular $\mathrm{Na}^{+}$. This event results at high intracellular $\mathrm{Na}^{+}$activity in 1.2-2.4-fold higher cell surface expression, and 2.8-3.5-fold higher average current per channel in Liddle mutants compared with the wild type. In addition, we show that a rapid increase in the intracellular $\mathrm{Na}^{+}$activity induced downregulation of the activity of wild-type $\mathrm{ENaC}$, but not Liddle mutants, on a time scale of minutes, which was directly correlated to the magnitude of the $\mathrm{Na}^{+}$influx into the oocytes. Feedback inhibition of $\mathrm{ENaC}$ by intracellular $\mathrm{Na}^{+}$likely represents an important cellular mechanism for controlling $\mathrm{Na}^{+}$reabsorption in the distal nephron that has important implications for the pathogenesis of hypertension. (J. Clin. Invest. 1998. 101: 2741-2750.) Key words: amiloride • feedback inhibition • hypertension $\cdot \mathrm{ENaC} \cdot$ aldosterone
\end{abstract}

\section{Introduction}

The epithelial $\mathrm{Na}$ channel $(\mathrm{ENaC})^{1}$ is a highly selective amiloride-sensitive $\mathrm{Na}$ channel found in the apical membrane of epithelial cells from different aldosterone target tissues, including the distal nephron, the distal colon, exocrine gland ducts, and the lung and the skin $(1,2)$. In these polarized cells, $\mathrm{Na}^{+}$entry into the cell from the apical surface via ENaC represents the rate-limiting step for the vectorial electrogenic movement of $\mathrm{Na}^{+}$. In the distal nephron, $\mathrm{ENaC}$ activity is regulated

Address correspondence to Laurent Schild, Institut de Pharmacologie et de Toxicologie, Bugnon 27, CH-1005 Lausanne, Switzerland. Phone: 011-4121-692-5380; FAX: 011-4121-692-5355; E-mail: Laurent. Schild@ipharm.unil.ch

Received for publication 16 January 1997 and accepted in revised form 30 March 1998.

1. Abbreviations used in this paper: cRNA, complementary ribonucleic acid, $\mathrm{ENaC}$, epithelial sodium channel, $\mathrm{g}_{\mathrm{Na}}$, amiloride-sensitive whole-cell conductance; $\mathrm{I}_{\mathrm{Na}}$, amiloride-sensitive whole-cell current, $\mathrm{M}_{2} \mathrm{Ab}$, anti-FLAG M2 mouse monoclonal antibody; MBS, modified Barth's solution; WT, wild-type.

J. Clin. Invest.

(C) The American Society for Clinical Investigation, Inc. 0021-9738/98/06/2741/10 \$2.00

Volume 101, Number 12, June 1998, 2741-2750

http://www.jci.org by aldosterone and vasopressin, serving to maintain $\mathrm{Na}^{+}$balance, extracellular volume, and blood pressure. Functional $\mathrm{ENaC}$ at the cell surface is a heterotetrameric protein composed of three homologous subunits assembled according to a preferential stoichiometry of $2 \alpha, 1 \beta$, and $1 \gamma$ subunits (3). Each subunit consists of a large extracellular hydrophilic loop flanked by two hydrophobic domains that span the membrane. The biophysical properties and pharmacological profile of ENaC expressed in Xenopus oocytes are similar to those of the native channel in the distal nephron (4). $\mathrm{ENaC}$ is constitutively active, but the open probability of the channel varies considerably from channel to channel, and factors regulating channel activity remain to be clearly identified.

The physiological importance of $\mathrm{ENaC}$ is emphasized by the recent finding that mutations in the $\beta$ and $\gamma$ subunits are associated with Liddle syndrome, an inherited form of saltsensitive hypertension $(5,6)$. Mutations that cause truncation of the $\mathrm{COOH}$ terminus after the second transmembrane domain of $\beta$ or $\gamma$ subunits, and single point mutations in the $\mathrm{COOH}$ terminus of the $\beta$ subunit were found in patients with Liddle syndrome $(7,8)$. Coexpression in Xenopus oocytes of the mutated or truncated $\beta$ subunits with wild-type (WT) rat $\alpha$ and $\gamma$ subunits, and of the truncated $\gamma$ subunit with WT rat $\alpha$ and $\beta$ subunits, resulted in a marked increase in amiloride-sensitive current compared with the current resulting from expression of WT ENaC subunits, consistent with a gain-of-function mutation causing increased renal $\mathrm{Na}^{+}$reabsorption in vivo (9). Comparison of the amiloride-sensitive current and of cell-surface expression of WT ENaC and $\mathrm{ENaC}$ containing the Liddle mutation that causes truncation of the $\mathrm{COOH}$-terminal tail of the $\beta$ subunit, showed that in mutant channels, amiloride-sensitive current was increased five to sixfold, and surface expression was increased twofold over WT (10). This result indicates that the effect of this Liddle mutation is partially due to a higher number of channels at the cell surface, but also to an increased current per channel of mutant compared with WT channels. Further mutational analysis showed that a short proline-rich segment in the cytoplasmic $\mathrm{COOH}$ terminus of $\beta$ and $\gamma$ subunits is required for normal regulation of channel activity. Missense mutations altering a consensus PPPxY sequence reproduced the increase in channel activity found in mutants in which the entire cytoplasmic $\mathrm{COOH}$ termini are deleted (11, 12). This proline-rich segment, referred to as PY motif, is known to be a binding site for proteins bearing a WW domain (13). Recently, Nedd4, a protein containing WW domains and a ubiquitin protein ligase domain, has been shown to bind specifically to the intact PY motif of $\beta$ and $\gamma \mathrm{ENaC}$ subunits, indicating that the PY motifs might be important for regulating ENaC stability (14).

In this study, we observed that the difference between $\mathrm{ENaC}$ WT and Liddle mutants in current expression was only significant when oocytes were loaded with $\mathrm{Na}^{+}$. No difference between WT and mutants was found when $\mathrm{Na}^{+}$was kept low. We show that WT ENaC is downregulated by intracellular 
$\mathrm{Na}^{+}$, and that mutant channels show a decrease in their sensitivity to $\mathrm{Na}^{+}$-dependent inhibition. We conclude that the Liddle mutations interfere with $\mathrm{Na}^{+}$-dependent regulation of channel function and expression.

\section{Methods}

ENaC expression. Site-directed mutagenesis was performed on rat ENaC cDNA as described previously (15). Complementary RNAs (cRNAs) of each subunit were synthetized in vitro. For binding experiments, $\alpha, \beta$, and $\gamma$ subunits were used that had been tagged as described by Firsov et al. (10) with the FLAG reporter octapeptide in the extracellular loop, directly $\mathrm{COOH}$-terminal of the first transmembrane segment of each subunit. Healthy stage V and VI Xenopus oocytes were pressure-injected with $100 \mathrm{nl}$ of a solution containing equal amounts of $\alpha \beta \gamma \mathrm{ENaC}$ subunits at a total concentration of $1-100 \mathrm{ng} / \mu \mathrm{l}$ in experiments in which the short-term effect of $\mathrm{Na}^{+}$regulation was measured, and at $100 \mathrm{ng} / \mu \mathrm{l}$ in all other experiments. During the expression phase, the oocytes were kept in modified Barth's saline (MBS) at different $\mathrm{Na}^{+}$activities (Table I).

Electrophysiological measurements and data analysis. Standard electrophysiological measurements were taken at the times indicated, or 16-20 h after injection. Macroscopic amiloride-sensitive $\mathrm{Na}^{+}$currents, defined as the difference between $\mathrm{Na}^{+}$currents obtained in the presence and absence of $5 \mu \mathrm{M}$ amiloride (SIGMA, Buchs, Switzerland) in the bath were recorded using the two-electrode voltageclamp technique. For current measurements, the oocytes were voltage-clamped to $-100 \mathrm{mV}$. The bath solution was a standard oocyte Ringer solution containing $95 \mathrm{mM} \mathrm{Na}^{+}$activity (Table I). Oocytes were initially placed in a bath solution containing amiloride to prevent changes in $[\mathrm{Na}]_{i}$, and current was measured after amiloride washout. Currents were recorded with a TEV-200 amplifier (Dagan Corp., Minneapolis, MN). Pulses for current-voltage curves were applied, and data were acquired using the Atari-based data acquisition system for the EPC-9 amplifier (HEKA Elektronik, Lambrecht, Germany). For current-voltage curves, 10 pulses lasting $150 \mathrm{~ms}$ from -100 $\mathrm{mV}$ to $+80 \mathrm{mV}$ were applied in the presence and absence of amiloride. Currents were filtered at $200 \mathrm{~Hz}$, and were digitized at 200 $\mathrm{Hz}$ for analysis. Since the current-voltage relationship of the macroscopic amiloride-sensitive current is not linear, macroscopic conductance was calculated from the steepness of the current-voltage relationship between -100 and $-80 \mathrm{mV}$. The intracellular $\mathrm{Na}^{+}$activity $\left[\mathrm{Na}^{+}\right]_{i}$ was calculated from the reversal potential $\left(E_{\text {rev }}\right)$ using the ENaC-expressing oocyte membrane as a highly selective probe. $\mathrm{E}_{\mathrm{rev}}$

Table I. Solutions for Oocyte Incubation and Current Measurements

\begin{tabular}{lccc}
\hline & $\mathrm{High} \mathrm{Na}^{+} \mathrm{MBS}$ & Low Na$^{+} \mathrm{MBS}$ & $\begin{array}{c}\text { Test solution } \\
\text { (frog ringer) }\end{array}$ \\
\hline & $m M$ & $m M$ & $m M$ \\
$\mathrm{NaCl}$ & 85 & 1 & 110 \\
$\mathrm{KCl}$ & 1 & 40 & 2.5 \\
$\mathrm{NaHCO}$ & & - & - \\
$N$-methyl-D-glutamine & - & 60 & - \\
$\mathrm{CaCl}_{2}$ & 0.4 & 0.4 & 1.8 \\
$\mathrm{Ca}\left(\mathrm{NO}_{3}\right)_{2}$ & 0.3 & 0.3 & - \\
$\mathrm{MgSO}_{4}$ & 0.8 & 0.8 & - \\
$\mathrm{Hepes}$ & 10 & 10 & 10 \\
$\mathrm{pH}$ & $7.2(\mathrm{NaOH})$ & $7.2(\mathrm{HCl})$ & $7.2(\mathrm{NaOH})$ \\
$\mathrm{Na}$ & 69 & 1 & 95 \\
& & & \\
\hline
\end{tabular}

$\mathrm{Na}^{+}$activities were calculated from concentrations as described in the Methods section. was determined from complete current-voltage curves over the voltage range of -100 to $+80 \mathrm{mV}$ of the amiloride-sensitive current as follows:

$$
[N a]_{i}=\frac{[N a]_{e x t}}{e^{E r e v / k}}
$$

where $\left[\mathrm{Na}^{+}\right]_{e x t}=$ external $\mathrm{Na}^{+}$activity, and $k=\mathrm{RT} / \mathrm{F}=25.26$ at $20^{\circ} \mathrm{C}$. The above equation is strictly valid only if the activity of ions is used for the concentration terms. Activities of ions in solution were calculated as follows. The activity $a$ for any species $i$ in solution is given by the product of the activity coefficient $f_{i}$ and its molar concentration $[x]$

$a_{i}=f_{i}[x]$.

At an ionic strength $<0.5 \mathrm{M}$, the Davies equation can be used to calculate the activity coefficient $f_{i}$ for any species $i$ of valence $z$ (16):

$\log _{10} f_{i}=-0.590 z^{2}\left(\frac{\sqrt{I}}{1+\sqrt{I}}-0.2 I\right)$

The ionic strength, $I$, is defined as the half sum of the product $c_{i} z_{i}^{2}$ for all ionic species in the solution where $c_{i}$ is the concentration and $z_{i}$ is the valence of species $i$. Values for $f_{i}$ obtained for the various MBS and the oocyte Ringer solution were in the range of 0.7-0.8. Data are shown as mean \pm SEM.

Binding experiments. The FLAG reporter octapeptide that had been introduced in $\alpha, \beta$, and $\gamma$ subunits is recognized by the antiFLAG $\mathrm{M}_{2}\left(\mathrm{M}_{2} \mathrm{Ab}\right)$ mouse monoclonal antibody (Eastman Kodak Co., Rochester, NY). $\mathrm{M}_{2} \mathrm{Ab}$ was iodinated as described by Firsov et al. (10). Iodinated $\mathrm{M}_{2} \mathrm{Ab}$ had a specific activity of $5-20 \times 10^{17} \mathrm{cpm} / \mathrm{mol}$, and was used for up to $2 \mathrm{mo}$ after synthesis. For the binding assay, oocytes were transferred into a 2-ml Eppendorf tube containing MBS of the $\mathrm{Na}^{+}$activity used during the channel expression supplemented with $10 \%$ heat-inactivated calf serum, and incubated for $30 \mathrm{~min}$ on ice. Binding was started upon addition of $12 \mathrm{nM}\left[{ }^{125} \mathrm{I}\right] \mathrm{M}_{2} \mathrm{Ab}$ (final concentration) in a volume of 5-6 $\mu \mathrm{l} /$ oocyte. After $1 \mathrm{~h}$ of incubation on ice, the oocytes were washed eight times with $1 \mathrm{ml}$ MBS of the appropriate $\mathrm{Na}^{+}$activity supplemented with $5 \%$ heat-inactivated calf serum, and were then transferred individually into tubes containing $250 \mu \mathrm{l}$ of the same solution for $\gamma$ counting. The samples were counted, and the same oocytes were kept for subsequent measurement of the whole-cell current. Nonspecific binding was determined from parallel assays of noninjected oocytes.

\section{Results}

Time course of ENaC activity expression. In a previous study we have shown that the $\mathrm{COOH}$ terminus deletion mutation of the $\mathrm{ENaC} \beta$ subunit causing Liddle syndrome increases both the number of channel molecules at the cell surface and the amiloride-sensitive current per channel expressed (10). The time course of appearance of significant differences between the amiloride-sensitive whole-cell current $\left(\mathrm{I}_{\mathrm{Na}}\right)$ of WT and mutant channels after cRNA injection helped us to identify the possible mechanism involved in the different regulation of WT and mutant ENaC. Experiments were carried out with WT $\mathrm{ENaC}$, and with a mutant $\mathrm{ENaC}$ containing the mutation $\beta$ R564stop, which introduces a premature stop codon in the $\mathrm{COOH}$ terminus of the $\beta$ subunit, and has been reported in the original Liddle pedigree (5). WT or mutant $\mathrm{ENaC}$ were expressed by coinjecting cRNAs encoding the three ENaC subunits: $\alpha, \beta$, and $\gamma$. Channel activity was assessed by measuring $\mathrm{I}_{\mathrm{Na}}$ in the presence of $95 \mathrm{mM}$ extracellular $\mathrm{Na}^{+}$activity (test solution, see Table I) at a holding potential of $-100 \mathrm{mV}$. In Fig. 1 $A$, the time course of $\mathrm{I}_{\mathrm{Na}}$ expressed by WT and $\alpha \beta$ R564stop $\gamma$ 
mutant channels was followed for $48 \mathrm{~h}$ under conditions where injected oocytes were maintained in an incubation medium containing a high $\mathrm{Na}^{+}$activity (high $\mathrm{Na}^{+}$MBS, Table I). $4 \mathrm{~h}$ after cRNA injection, a small $\mathrm{I}_{\mathrm{Na}}(10-200 \mathrm{nA})$ was measured, and for up to $7 \mathrm{~h}$ no significant difference in channel activity was detected between WT and mutant channels. Thus, during this period Liddle mutations do not result in an altered channel appearance rate at the cell surface. After $10 \mathrm{~h}$, the magnitude of $\mathrm{I}_{\mathrm{Na}}$, expressed by $\mathrm{WT} \mathrm{ENaC}$, reached a steady state, and saturated at a value close to $3 \mu \mathrm{A}$, whereas $\mathrm{I}_{\mathrm{Na}}$ in $\alpha \beta R 564$ stop $\gamma$-injected oocytes increased steadily over the 48 -h period. Therefore, the difference in channel activity between WT and mutant became more evident with time, and was significantly different at times $\geq 8 \mathrm{~h}$ after cRNA injection.

We have previously shown that WT ENaC activity increased when $\mathrm{Na}^{+}$activity in the medium for oocyte incubation was low (10). We addressed the question of $\mathrm{Na}^{+}$influence on activity of WT channel and Liddle mutants by repeating the time course experiments of $\mathrm{I}_{\mathrm{Na}}$ expression in oocytes incubated

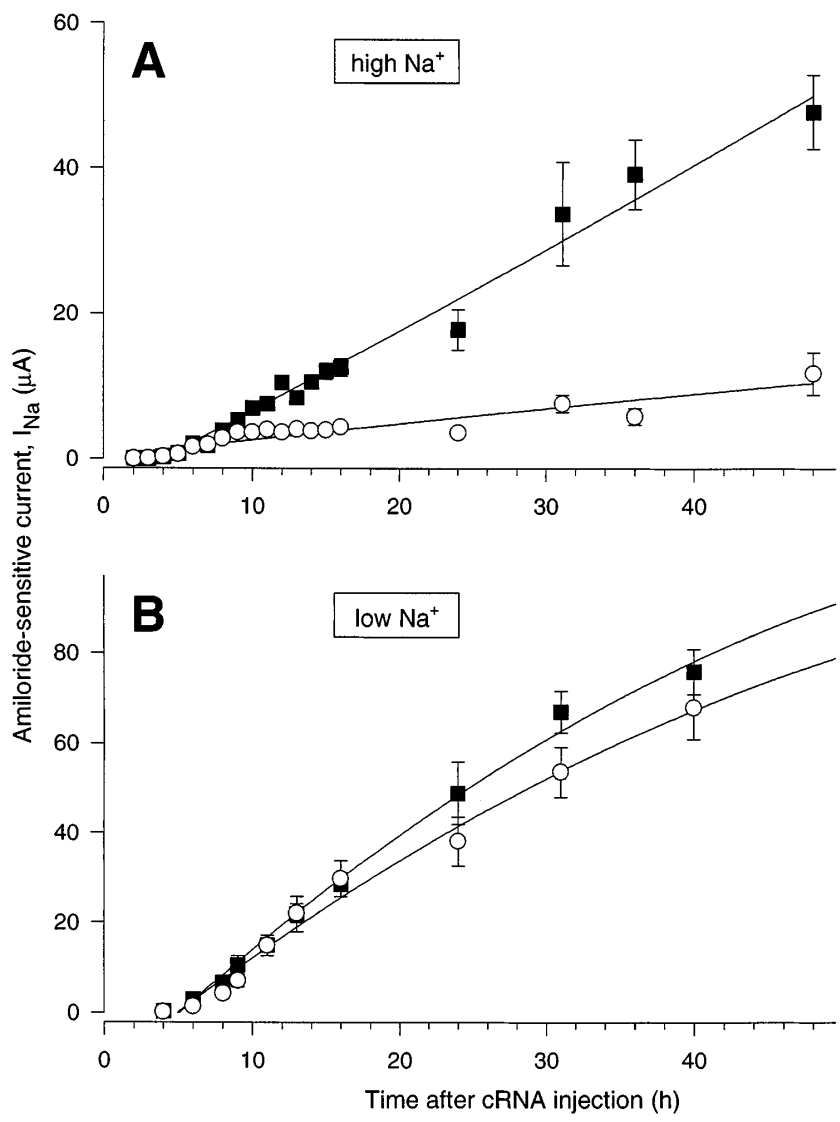

Figure 1. Time course of WT and mutant ENaC expression in high and low $\mathrm{Na}^{+}$MBS. cRNA encoding either WT or mutant $\alpha \beta R 564$ stop $\gamma \mathrm{ENaC}$ was injected into oocytes, which were subsequently incubated in high $(A)$ or low $(B) \mathrm{Na}^{+}$medium (MBS, Table I). At intervals, oocytes were taken for current measurement. Currents were measured in a high $\mathrm{Na}^{+}$test solution (Table I) at a holding potential of $-100 \mathrm{mV}$. Data shown for WT $(\bigcirc)$ and $\alpha \beta R 564$ stop $\gamma$

(घ) $\mathrm{ENaC}$ are from 5-42 oocytes from a total of 8 (high $\mathrm{Na}^{+} \mathrm{MBS}$ ) or 4 (low $\mathrm{Na}^{+}$MBS) batches. The lines are second order polynomial regressions, and error bars represent the SEM. For many data points the SEM was smaller than the symbol. in a $1-\mathrm{mM} \mathrm{Na}^{+}$incubation medium (low $\mathrm{Na}^{+} \mathrm{MBS}$, Table I) after cRNA injection (Fig. $1 B$ ). $\mathrm{I}_{\mathrm{Na}}$ was measured under conditions identical to those in Fig. $1 A$ in an oocyte Ringer solution containing $95 \mathrm{mM}\left[\mathrm{Na}^{+}\right]_{\text {ext }}$ at a holding potential of -100 $\mathrm{mV}$. After incubation in the low $\mathrm{Na}^{+}$medium, no saturation of channel activity was observed either for the Liddle mutant or for the WT ENaC, and there was no significant difference between WT and mutant $\mathrm{I}_{\mathrm{Na}}$. Taken together, these experiments provide evidence that in a high- $\mathrm{Na}^{+}$environment (Fig. $1 A$ ), WT channel activity is drastically repressed as shown by a maximal $\mathrm{I}_{\mathrm{Na}}$ that levels off around $3 \mu \mathrm{A}$, while the Liddle truncation mutant is not efficiently downregulated, and expressed $\mathrm{I}_{\mathrm{Na}}$ does not reach saturation over a 48-h period. In a low $\mathrm{Na}^{+}$ environment (Fig. $1 B$ ), $\mathrm{I}_{\mathrm{Na}}$ expression of WT and the Liddle mutant was similar, and increased over the whole time period of the experiment. This result suggests that the Liddle mutation interferes with a $\mathrm{Na}^{+}$-dependent downregulation of $\mathrm{ENaC}$.

Downregulation of WT ENaC in a high $\mathrm{Na}^{+}$environment became evident only at times $\geq 8 \mathrm{~h}$ after cRNA injection (Fig. $1 A)$. ENaC expressed in these oocytes is constitutively active, and generates a significant $\mathrm{Na}^{+}$conductance in the plasma membrane. Thus, after ENaC cRNA injection, the number of active $\mathrm{ENaC}$ at the plasma membrane increases, allowing $\mathrm{Na}^{+}$ entry into the cell, and a rise in the intracellular $\mathrm{Na}^{+}$activity $\left(\left[\mathrm{Na}^{+}\right]_{\mathrm{i}}\right)$. This increase in $\left[\mathrm{Na}^{+}\right]_{\mathrm{i}}$ may be responsible for downregulation of WT ENaC activity, which would explain the late onset of ENaC downregulation. We have calculated $\left[\mathrm{Na}^{+}\right]_{\mathrm{i}}$ from measurements of the reversal potential of $\mathrm{I}_{\mathrm{Na}}$ (see Methods) in experiments illustrated in Fig. $1 A$. In a large cell such as the Xenopus oocyte, these measurements reflect $\left[\mathrm{Na}^{+}\right]_{\mathrm{i}}$ in a cytosolic compartment close to the plasma membrane, and cannot be extrapolated to the overall $\left[\mathrm{Na}^{+}\right]_{\mathrm{i}}$ in the cytoplasm. As shown in Table II, the $\left[\mathrm{Na}^{+}\right]_{\mathrm{i}}$ increased from $\sim 12 \mathrm{mM}$ at $4 \mathrm{~h}$ up to $\sim 60 \mathrm{mM}$ at $8 \mathrm{~h}$, which indicates that intracellular $\mathrm{Na}^{+}$ almost equilibrates with extracellular $\mathrm{Na}^{+}$across the ENaCexpressing plasma membrane. $\left[\mathrm{Na}^{+}\right]_{\mathrm{i}}$ of WT and $\alpha \beta \mathrm{R} 564$ stop $\gamma-$ expressing oocytes were similar (Table II). Incubation of oocytes in a low $\mathrm{Na}^{+}$environment limited $\mathrm{Na}^{+}$entry, and prevented cell overload by $\mathrm{Na}^{+}$ions. After $20 \mathrm{~h}$ of incubation in $1 \mathrm{mM} \mathrm{Na}^{+} \mathrm{MBS},\left[\mathrm{Na}^{+}\right]_{\mathrm{i}}$ remained low at $\sim 2 \pm 0 \mathrm{mM}$ for both WT $(n=34)$ and $\alpha \beta R 564$ stop $\gamma$ mutants $(n=32)$, and under these conditions WT channels were not downregulated (Fig. 1 $B)$. Thus, saturation of the activity of WT channels in a high $\mathrm{Na}^{+}$environment that was reached shortly after the main increase in $\left[\mathrm{Na}^{+}\right]_{\mathrm{i}}$ (Fig. $1 A$, Table II) may well reflect downregulation of $\mathrm{ENaC}$ in response to the rise in $\left[\mathrm{Na}^{+}\right]_{\mathrm{i}}$.

The dependence of WT ENaC activity on $\left[\mathrm{Na}^{+}\right]_{i}$ was further investigated by loading the oocytes with different amounts of $\mathrm{Na}^{+}$. To obtain different intracellular $\mathrm{Na}^{+}$activities, oocytes were incubated overnight in solutions of varying $\mathrm{Na}^{+}$activities. The relationship between $\left[\mathrm{Na}^{+}\right]_{\text {ext }}$ and $\left[\mathrm{Na}^{+}\right]_{i}$ was determined for extracellular $\mathrm{Na}^{+}$activities ranging from 1-90 mM Na+ (Fig. $2 A$ ). We observed a linear correlation between extracellular and intracellular $\mathrm{Na}^{+}$activities consistent with $\mathrm{Na}^{+}$equilibration across the plasma membrane of oocytes expressing $\mathrm{ENaC}$ (Fig. $2 A$ ). At a given $\left[\mathrm{Na}^{+}\right]_{\mathrm{ext}},\left[\mathrm{Na}^{+}\right]_{\mathrm{i}}$ was only slightly $(6 \pm 3 \%)$ higher for $\alpha \beta R 564$ stop $\gamma(\boldsymbol{\square})$ than for WT $(\bigcirc)$, indicating that for both channel types expressed at the cell membrane, the resulting membrane permeability to $\mathrm{Na}^{+}$was high enough to allow $\mathrm{Na}^{+}$equilibration across the plasma membrane after 16-20 h. To obtain an estimate of the 
Table II. Changes in the Intracellular $\mathrm{Na}^{+}$Activity $\left[\mathrm{Na}^{+}\right]_{i}$ of Xenopus Oocytes During the Expression of ENaCs in $69 \mathrm{mM}$ $\mathrm{Na}^{+}$Medium

\begin{tabular}{|c|c|c|c|c|c|c|c|c|}
\hline \multirow{2}{*}{ Time after cRNA injection } & \multicolumn{2}{|c|}{$4 \mathrm{~h}$} & \multicolumn{2}{|c|}{$6 \mathrm{~h}$} & \multicolumn{2}{|c|}{$8 \mathrm{~h}$} & \multicolumn{2}{|r|}{$20 \mathrm{~h}$} \\
\hline & WT & $\beta$ R564 stop & WT & $\beta$ R564 stop & WT & $\beta$ R564 stop & WT & $\beta$ R564 stop \\
\hline$\left[\mathrm{Na}^{+}\right]_{\mathrm{i}}(\mathrm{mM})$ & $13 \pm 3$ & $11 \pm 1$ & $43 \pm 1$ & $45 \pm 2$ & $54 \pm 1$ & $58 \pm 2$ & $52 \pm 1$ & $56 \pm 1$ \\
\hline
\end{tabular}

$\left[\mathrm{Na}^{+}\right]_{\mathrm{i}}$ was calculated from 7-45 oocytes per condition as described in the Methods section. Errors represent the SEM.
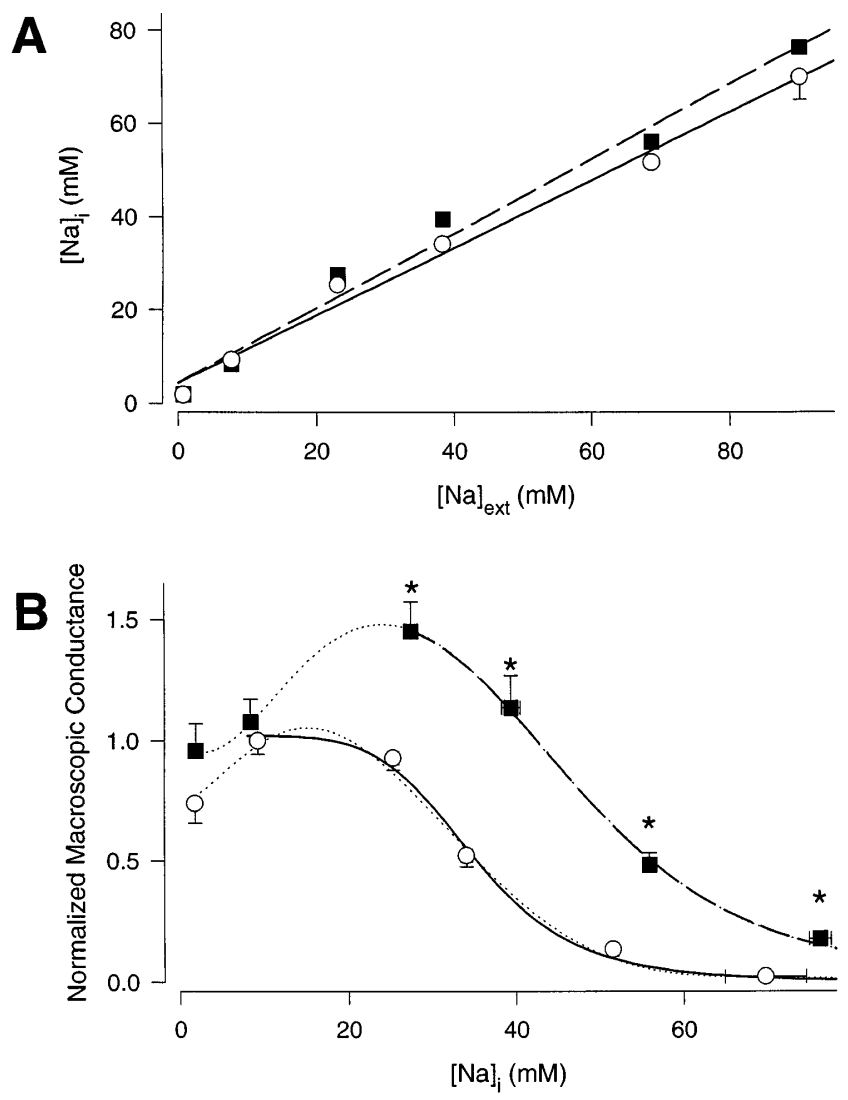

Figure 2. $\mathrm{Na}^{+}$dependence of ENaC activity. (A) Correlation of extracellular and intracellular $\mathrm{Na}^{+}$activity of ENaC-expressing oocytes. Groups of oocytes expressing WT or mutant $\mathrm{ENaC}$ were incubated overnight in MBS containing different $\mathrm{Na}^{+}$activities $\left(\left[\mathrm{Na}^{+}\right]_{\text {ext }}, 1,8\right.$, $23,38,69$, and $90 \mathrm{mM})$. The intracellular $\mathrm{Na}^{+}$activity $\left[\mathrm{Na}^{+}\right]_{\mathrm{i}}$ was calculated from the reversal potential of the amiloride-sensitive current (see Methods) measured in an oocyte Ringer solution of a similar $\mathrm{Na}^{+}$activity as the storage MBS. Data for WT $(\bigcirc)$ and $\alpha \beta R 564$ stop $\gamma$ (घ) ENaC from 23-58 oocytes and 3-5 batches per condition are shown. The regression to the WT data, shown as a solid line, is: $\left[\mathrm{Na}^{+}\right]_{\mathrm{i}}$ $($ activity, $\mathrm{mM})=0.72 \times\left[\mathrm{Na}^{+}\right]_{\mathrm{ext}}(\mathrm{mM})+4.4 \mathrm{mM}$, and the regression to the $\alpha \beta R 564$ stop $\gamma$ data, shown as an interrupted line, is: $\left[\mathrm{Na}^{+}\right]_{\mathrm{i}}(\mathrm{ac}-$ tivity, $\mathrm{mM})=0.80 \times\left[\mathrm{Na}^{+}\right]_{\mathrm{ext}}(\mathrm{mM})+4.4 \mathrm{mM} .(B)\left[\mathrm{Na}^{+}\right]_{\mathrm{i}}$ dependence of the downregulation of WT ENaC activity. From the same oocytes as used for the experiment described in $A$, the conductance in an oocyte Ringer solution of $95 \mathrm{mM}\left[\mathrm{Na}^{+}\right]_{\text {ext }}$ was subsequently measured as described in Methods. Data for WT $(\bigcirc)$ and $\alpha \beta R 564$ stop $\gamma$ (ם) ENaC from 23-58 oocytes and 3-5 batches per condition are shown. For each batch of oocytes, $\mathrm{g}_{\mathrm{Na}}$ values of WT and the $\alpha \beta$ R564stop $\gamma$ mutant were normalized to the $\mathrm{WT} \mathrm{g}_{\mathrm{Na}}$ at $8 \mathrm{mM}$ $\left[\mathrm{Na}^{+}\right]_{\text {ext }}$. Absolute $\mathrm{g}_{\mathrm{Na}}$ values at $8 \mathrm{mM}\left[\mathrm{Na}^{+}\right]_{\text {ext }}$ in paired experiments were $348 \pm 32 \mu \mathrm{S} /$ oocyte for WT $(n=31)$ and $331 \pm 27 \mu$ S/oocyte for $\alpha \beta$ R564stop $\gamma(n=30)$. The dotted lines are polynomial regressions,
$\mathrm{Na}^{+}$dependence of ENaC regulation, oocytes expressing WT or mutant $\mathrm{ENaC}$ were incubated overnight in MBS of various $\mathrm{Na}^{+}$activities, and channel activity was determined as the amiloride-sensitive $\mathrm{Na}^{+}$conductance ( $\mathrm{g}_{\mathrm{Na}}$, see Methods) in 95 $\mathrm{mM} \mathrm{Na}{ }^{+}$oocyte Ringer medium. $\mathrm{g}_{\mathrm{Na}}$ is plotted as a function of $\left[\mathrm{Na}^{+}\right]_{\mathrm{i}}$ in Fig. 2 B. For each batch of oocytes, $\mathrm{g}_{\mathrm{Na}}$ values of WT and the $\alpha \beta R 564$ stop $\gamma$ mutant were normalized to the $\mathrm{WT} \mathrm{g}_{\mathrm{Na}}$ at $8 \mathrm{mM}\left[\mathrm{Na}^{+}\right]_{\text {ext }}$. For WT ENaC $(O)$, the dependency of $\mathrm{g}_{\mathrm{Na}}$ on $\left[\mathrm{Na}^{+}\right]_{\mathrm{i}}$ yielded a bell-shaped curve with a maximum at $\sim 10$ $\mathrm{mM}\left[\mathrm{Na}^{+}\right]_{\mathrm{i}}$, a 1.4 -fold lower $\mathrm{g}_{\mathrm{Na}}$ at $1 \mathrm{mM}\left[\mathrm{Na}^{+}\right]_{\mathrm{i}}$, and, towards higher $\left[\mathrm{Na}^{+}\right]_{i}$, a sharp decrease of $\mathrm{g}_{\mathrm{Na}}$ at $\left[\mathrm{Na}^{+}\right]_{\mathrm{i}}>25 \mathrm{mM}$. Fitting the WT data at $\left[\mathrm{Na}^{+}\right]_{\mathrm{i}} \geq 9 \mathrm{mM}$ to an inhibition equation (see legend to Fig. 2) yielded an apparent inhibitory constant of $35 \mathrm{mM}$ and a pseudo-Hill coefficient of 6. For $\alpha \beta R 564$ stop $\gamma$ (ם), the $\mathrm{Na}^{+}$dependency of $\mathrm{g}_{\mathrm{Na}}$ had a similar shape, but it was shifted to higher $\left[\mathrm{Na}^{+}\right]_{i}$. Fitting the mutant data at $\left[\mathrm{Na}^{+}\right]_{\mathrm{i}} \geq 27$ $\mathrm{mM}$ yielded an apparent inhibitory constant of $48 \mathrm{mM}$ and a pseudo-hill coefficient of 5. Thus, the Liddle mutant shows a decreased sensitivity to inhibition by $\left[\mathrm{Na}^{+}\right]_{\mathrm{i}}$.

Comparison of current and cell surface expression of mutant and WT ENaC in Xenopus oocytes. The lower sensitivity of the Liddle truncation mutant to intracellular $\mathrm{Na}^{+}$compared with $\mathrm{ENaC}$ WT raises a number of questions. First, is this effect specifically related to mutations of a conserved PY motif in the $\mathrm{COOH}$ terminus of $\mathrm{ENaC}$ subunits that have been reported to cause Liddle syndrome (5-7)? Second, does intracellular $\mathrm{Na}^{+}$affect channel density and/or the average current per channel at the cell surface? To address these issues we compared in the same experiments the effect of the $\beta$ R564stop truncation mutation and the two missense mutations in the subunit PY motif $\beta$ P616L and $\beta$ Y618A, on the current expression and the number of channels at the cell surface. ENaC activity measured as $\mathrm{I}_{\mathrm{Na}}$ under our standard conditions (in the presence of $95 \mathrm{mM}\left[\mathrm{Na}^{+}\right]_{\text {ext }}$ at $-100 \mathrm{mV}$ holding potential) was correlated in the same oocyte with expression of ENaC subunits at the cell surface 16-20 h after cRNA injection (see Fig. 1). Fig. 3, $A-C$ summarizes the data obtained from direct comparison of WT ENaC and Liddle mutants under conditions of overnight incubation of oocytes in a high $\mathrm{Na}^{+}$-containing medium

and the solid and interrupted lines represents the fit to data points at $\left[\mathrm{Na}^{+}\right]_{\mathrm{i}} \geq 9 \mathrm{mM}(\mathrm{WT})$ and $\left[\mathrm{Na}^{+}\right]_{\mathrm{i}}(27 \mathrm{mM}(\alpha \beta \mathrm{R} 564$ stop $\gamma)$, respectively, to an inhibition equation: $\mathrm{g}_{\mathrm{Na}}=\mathrm{K}_{\mathrm{i}}^{\mathrm{n}^{\prime}} /\left(\mathrm{K}_{\mathrm{i}}^{\mathrm{n}^{\prime}}+\left[\mathrm{Na}^{+}\right]_{\mathrm{i}}\right)$, where $\mathrm{g}_{\mathrm{Na}}$ is the amiloride-sensitive whole-cell conductance, $\mathrm{K}_{\mathrm{i}}$ is the apparent inhibitory constant of the blocker, $\mathrm{n}^{\prime}$ is a pseudo-Hill coefficient, and $\left[\mathrm{Na}^{+}\right]_{\mathrm{i}}$ is the intracellular $\mathrm{Na}^{+}$activity. Fit parameters were $35 \mathrm{mM}$ $\left(\mathrm{K}_{\mathrm{i}}\right)$ and $6\left(\mathrm{n}^{\prime}\right)$ for WT, and $48 \mathrm{mM}\left(\mathrm{K}_{\mathrm{i}}\right)$ and $5\left(\mathrm{n}^{\prime}\right)$ for $\alpha \beta R 564$ stop $\gamma$. $* P<0.05$ vs. WT at the same $\left[\mathrm{Na}^{+}\right]_{\mathrm{ext}}$. Error bars represent the SEM. 

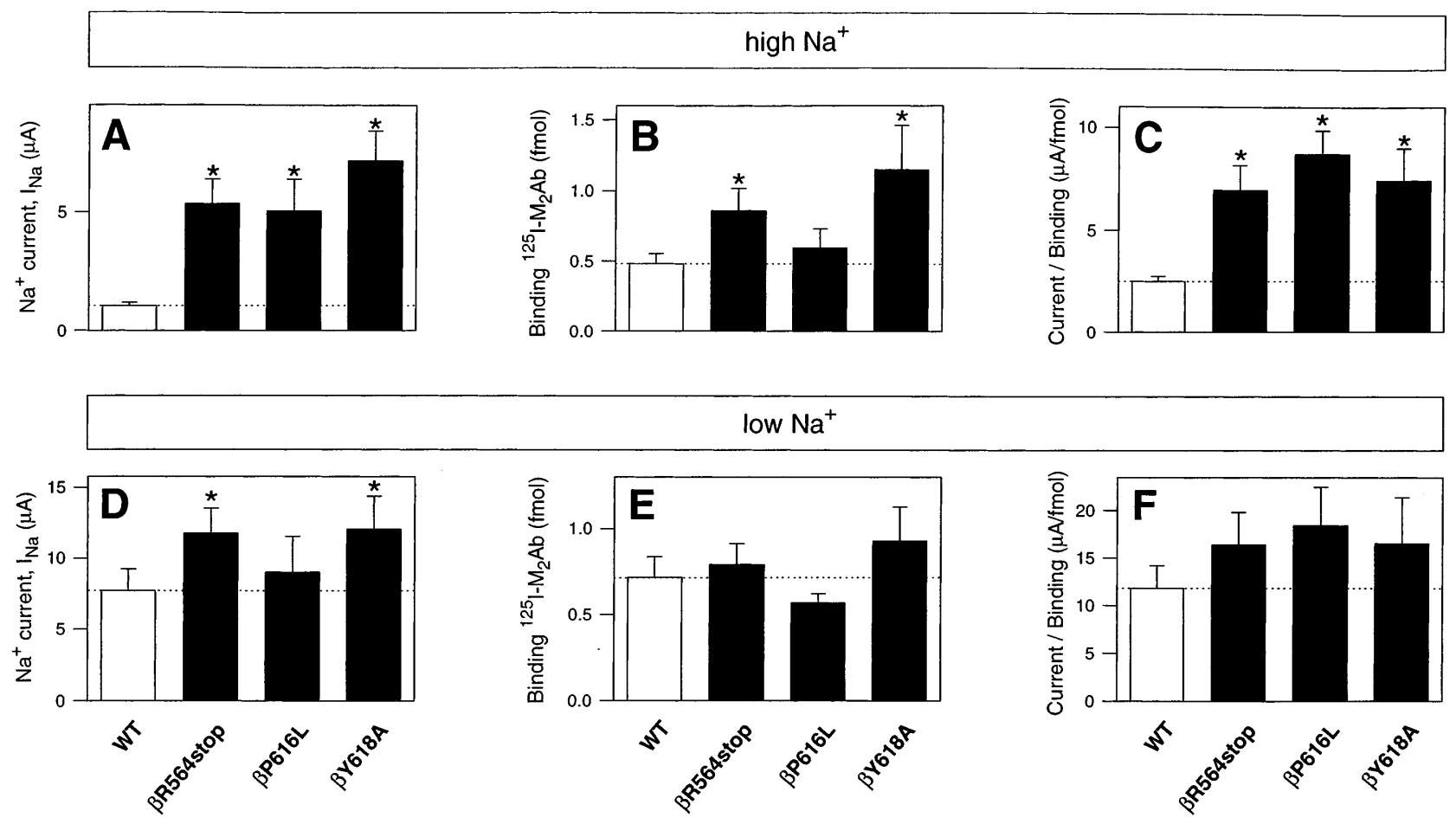

Figure 3. Effect of Liddle mutations on ENaC current and cell surface expression at two different extracellular $\mathrm{Na}^{+}$activities. Amiloride-sensitive whole-cell current $\left(\mathrm{I}_{\mathrm{Na}}, A\right.$ and $\left.D\right)$ and cell surface expression $\left(B\right.$ and $E$ ) were measured, and the ratio of $\mathrm{I}_{\mathrm{Na}} /$ cell surface expression $(C$ and $F$ ) was calculated from oocytes expressing WT $\alpha \beta \gamma \mathrm{ENaC}$ (open bars) or channels composed of WT $\alpha$ and $\gamma$ subunits and the mutant $\beta$ subunits $\beta$ R564stop, $\beta$ P616L, or $\beta$ Y618A (filled bars). $(A-C)$ Measurements were performed after overnight incubation in MBS of $69 \mathrm{mM} \mathrm{Na}^{+}$activity $\left(\left[\mathrm{Na}^{+}\right]_{\text {ext }}\right) .(D-F)$ Measurements were performed after overnight incubation in MBS of $8 \mathrm{mM}\left[\mathrm{Na}^{+}\right]_{\text {ext }}$. The data are from experiments in which the mutants were directly compared with WT for each of the two incubation conditions, but they are not direct comparisons of the two incubation conditions. Currents were measured in an oocyte Ringer solution of $95 \mathrm{mM}\left[\mathrm{Na}^{+}\right]_{\mathrm{ext}}$ at a holding potential of $-100 \mathrm{mV}$. [ $\left.{ }^{125} \mathrm{I}\right] \mathrm{M}_{2} \mathrm{Ab}$ binding and $\mathrm{I}_{\mathrm{Na}}$ were measured in the same oocytes. Data shown are from 7-13 experiments, each performed on 5-10 oocytes. * $P<0.05$ vs. WT at the same $\mathrm{Na}^{+}$activity. Error bars represent SEM.

(69 mM $\left[\mathrm{Na}^{+}\right]_{\text {ext }}$, which leads to an $\left[\mathrm{Na}^{+}\right]_{\mathrm{i}}$ of $\left.52-56 \mathrm{mM}\right) . \mathrm{I}_{\mathrm{Na}}$ was 4.8-6.8-fold higher in Liddle mutants relative to WT $\mathrm{ENaC}$ (Fig. $3 A$ ). Cell surface expression of ENaC subunits is expressed as fmol of iodinated monoclonal antibody $\left(\left[{ }^{125} \mathrm{I}\right] \mathrm{M}_{2} \mathrm{Ab}\right.$ ) specifically bound at the cell surface (Fig. $3 \mathrm{~B}$, see Methods). The amount of ENaC subunits detected was 1.8and 2.4-fold higher in oocytes expressing $\beta$ R564stop and the $\beta$ Y618A mutants compared with ENaC WT. For the $\beta$ P616L mutant, the 1.2-fold increase in Ab binding was not statistically significant. Thus, the higher cell surface expression of ENaC alone cannot account for the increase in $\mathrm{I}_{\mathrm{Na}}$ measured for the Liddle mutants, indicating that the average current per channel also increases. This is best shown by the ratios of whole-cell $\mathrm{I}_{\mathrm{Na}}$ over the number of $\left[{ }^{125} \mathrm{I}\right] \mathrm{M}_{2} \mathrm{Ab}$ binding sites at the cell surface, which was $2.5 \mu \mathrm{A} / \mathrm{fmol}$ for WT, and 7.0-8.7 $\mu \mathrm{A} / \mathrm{fmol}$ for the mutant channels (Fig. $3 \mathrm{C}$ ). Assuming that one antibody molecule binds to one ENaC subunit (10), and considering the four-subunit stoichiometry of the channel, the average $\mathrm{Na}^{+}$ current per channel at the cell surface is $1.7 \times 10^{-2} \mathrm{pA}$ for WT, and $4.6 \times 10^{-2}-5.9 \times 10^{-2} \mathrm{pA}$ for the mutants (3). These results indicate that the gain-of-function mutations in Liddle syndrome result from dual effects, an increased $\mathrm{ENaC}$ cell surface expression, and an increase in average current per channel allowing more $\mathrm{Na}^{+}$to flow through the channel.

Fig. 3, $D-F$ compare in the same experiments ENaC WT and mutants under conditions of overnight incubation in a medium of low $\mathrm{Na}^{+}$activity $\left(8 \mathrm{mM}\left[\mathrm{Na}^{+}\right]_{\mathrm{ext}}\right) . \mathrm{I}_{\mathrm{Na}}$ was measured under identical conditions to those in Fig. $3, A-C$ (i.e., in the presence of $95 \mathrm{mM}\left[\mathrm{Na}^{+}\right]_{\mathrm{ext}}$ at $-100 \mathrm{mV}$ holding potential). As expected from the $\left[\mathrm{Na}^{+}\right]_{\mathrm{i}}$ dependence of ENaC activity (Fig. 2 $B)$, the differences between WT and mutant ENaC regarding $\mathrm{I}_{\mathrm{Na}}$ and channel cell surface expression were considerably attenuated under these low $\mathrm{Na}^{+}$conditions. The $\mathrm{I}_{\mathrm{Na}}$ expressed by the $\beta$ R564stop and $\beta$ Y618A Liddle mutants were 1.5- and 1.6-fold higher than WT, and no significant difference in $\mathrm{I}_{\mathrm{Na}}$ was observed between the $\alpha \beta$ P616L $\gamma$ mutant and WT (Fig. 3 $D)$. Furthermore, there was no significant difference between Liddle mutants and WT for the cell surface expression (Fig. 3 $E$ ) or the current/channel ratio (Fig. $3 F$ ).

The experiments illustrated in Fig. 3 were designed to compare directly the effects of Liddle mutations on channel activity and expression with respect to $\mathrm{ENaC}$ WT under two independent conditions of low and high $\mathrm{Na}^{+}$in the incubation medium. Because of the variations of $\mathrm{I}_{\mathrm{Na}}$ between experiments, it remains difficult to assess precisely from these experiments the role of $\mathrm{Na}^{+}$on channel density at the cell surface and average current per channel. Using the same protocol, we have compared on the same batches of oocytes expressing WT $\mathrm{ENaC}$ or Liddle mutants, the magnitude of $\mathrm{I}_{\mathrm{Na}}$ and the number of ENaC subunits at the cell surface after overnight incubation 
Table III. Direct Comparison of the Effect of Low or High $\mathrm{Na}^{+}$Incubation Medium on Amiloride-sensitive Current and Cell Surface Expression of Wild-type and Mutant ENaC

\begin{tabular}{|c|c|c|c|c|c|}
\hline & Incubation & $\alpha \beta \gamma$ & $\alpha \beta_{\mathrm{R} 564 \mathrm{stop}} \gamma$ & $\alpha \beta_{\mathrm{P} 616 \mathrm{~L}} \gamma$ & $\alpha \beta_{\mathrm{Y} 618 \mathrm{~A}} \gamma$ \\
\hline \multirow[t]{2}{*}{$\mathrm{I}_{\mathrm{Na}^{+}}(\mu \mathrm{A})$} & $8 \mathrm{mM} \mathrm{Na}^{+}$ & $7.4 \pm 0.8^{*}$ & $13.3 \pm 1.6^{*}$ & $3.9 \pm 0.4 *$ & $12.4 \pm 1.7 *$ \\
\hline & $69 \mathrm{mM} \mathrm{Na}^{+}$ & $1.0 \pm 0.1$ & $4.6 \pm 0.4$ & $2.8 \pm 0.2$ & $6.9 \pm 0.5$ \\
\hline \multirow[t]{2}{*}[{}^{125}\mathrm{I}]{$\mathrm{M}_{2} \mathrm{Ab}$-binding (fmol) } & $8 \mathrm{mM} \mathrm{Na}^{+}$ & $0.90 \pm 0.07 *$ & $1.02 \pm 0.07$ & $0.27 \pm 0.03$ & $1.32 \pm 0.10$ \\
\hline & $69 \mathrm{mM} \mathrm{Na}^{+}$ & $0.44 \pm 0.04$ & $0.85 \pm 0.07$ & $0.33 \pm 0.03$ & $1.40 \pm 0.09$ \\
\hline
\end{tabular}

For each WT or mutant the effects of 8 and $69 \mathrm{mM} \mathrm{Na}^{+}$activity in the incubation medium on the amiloride-sensitive current and [25I] ${ }_{2} \mathrm{Ab}^{12}$ binding were compared in the same batch of oocytes at the same day. $\mathrm{I}_{\mathrm{Na}}$ was measured under standard conditions, i.e., $95 \mathrm{mM}\left[\mathrm{Na}^{+}\right]_{\mathrm{ext}}$ with the oocytes clamped to $-100 \mathrm{mV}$. Data are from 28-53 oocytes from 3-5 different batches. *Difference between the two incubation conditions $(P<0.05)$.

in $8 \mathrm{mM}$ or $69 \mathrm{mM} \mathrm{Na}^{+}$incubation medium. Table III shows that increasing $\left[\mathrm{Na}^{+}\right]_{\text {ext }}$ in the incubation medium from 8 to $69 \mathrm{mM}$ resulted, for WT ENaC, in an approximately sevenfold reduction in $\mathrm{I}_{\mathrm{Na}}$, whereas for Liddle mutants, $\mathrm{I}_{\mathrm{Na}}$ decreased only by approximately twofold under the same conditions $(P<0.05)$. This result reflects the lower sensitivity of the $\alpha \beta$ R564stop $\gamma$ mutant to inhibition by $\mathrm{Na}^{+}$(see Fig. $2 \mathrm{~B}$ ). The same increase in $\mathrm{Na}^{+}$activity in the incubation medium (8-69 $\mathrm{mM}$ ) reduced by a factor of two the number of WT ENaC detected at the cell surface. This decrease in channel expression alone could not account for the sevenfold reduction in $\mathrm{I}_{\mathrm{Na}}$, indicating that high $\mathrm{Na}^{+}$leads to both a reduction in the number of WT channels at the cell surface and a reduction of current per channel. For the Liddle mutants, changes in $\mathrm{Na}^{+}$activities in the incubation medium did not modify channel expression at the cell surface. These experiments provide evidence that high $\mathrm{Na}^{+}$downregulates WT ENaC by decreasing the average $\mathrm{Na}^{+}$ current per channel, and by decreasing channel expression at the cell surface. The Liddle mutants are less sensitive to downregulation of the activity per channel by $\mathrm{Na}^{+}$, and their expression is insensitive to $\mathrm{Na}^{+}$.

Short-term effect of intracellular $\mathrm{Na}^{+}$on ENaC function. The experiments presented so far show evidence that intracellular $\mathrm{Na}^{+}$modulates ENaC activity, and that the gain-of-function mutations in Liddle syndrome result in an inefficient downregulation of the channel in response to a rise in $\left[\mathrm{Na}^{+}\right]_{i}$. To obtain direct evidence for a feedback regulation of $\mathrm{ENaC}$ activity upon $\mathrm{Na}^{+}$entry into the cell as described by Frindt et al. (17), we have analyzed the time course of changes in $\mathrm{I}_{\mathrm{Na}}$ from the time $\mathrm{Na}^{+}$is allowed to flow into the cell. Oocytes were incubated in a low $\mathrm{Na}^{+}$MBS (Table I) during the expression phase to keep $\left[\mathrm{Na}^{+}\right]_{\mathrm{i}}$ as low as possible. At time zero, superfusion of the oocytes with a solution containing a high $\mathrm{Na}^{+}$activity (test solution, Table I) was started, and oocytes were voltage-clamped to $-100 \mathrm{mV}$ to favor rapid $\mathrm{Na}^{+}$influx. For $25 \mathrm{~min}$, channel activity was measured as amiloride-sensitive $\mathrm{Na}^{+}$ conductance $\mathrm{g}_{\mathrm{Na}}$. Fig. $4 \mathrm{~A}$ compares changes in $\mathrm{g}_{\mathrm{Na}}$ between WT ENaC and the mutants $\alpha \beta$ R564stop $\gamma, \alpha \beta$ P616L $\gamma$, and $\alpha \beta$ Y618A $\gamma$ over the 25 -min time period. The amounts of cRNA injected were adjusted to obtain a similar level of current expression of WT and mutant channels. In WT-expressing oocytes, $\mathrm{g}_{\mathrm{Na}}$ decreased rapidly upon entry of $\mathrm{Na}^{+}$ions with an exponential rate of $0.07 \mathrm{~min}^{-1}$ and a time delay of $\sim 10 \mathrm{~min}$, whereas in all three mutants the macroscopic conductance remained stable over the recording time. At $25 \mathrm{~min}$, macroscopic conductance was $85 \pm 7 \%(n=7)$ of the initial value for $\alpha \beta$ R564stop $\gamma, 88 \pm 6 \%(n=6)$ for $\alpha \beta$ P616L $\gamma$, and $91 \pm 10 \%$ $(n=4)$ for $\alpha \beta Y 618 A \gamma$ compared with $27 \pm 4 \%(n=7)$ for WT channels. Changes in $\left[\mathrm{Na}^{+}\right]_{i}$, measured from the reversal potential of $\mathrm{I}_{\mathrm{Na}}$ during the $\mathrm{Na}^{+}$influx are shown in Fig. $4 \mathrm{~B}$. $\left[\mathrm{Na}^{+}\right]_{\mathrm{i}}$ increased rapidly over the first $5 \mathrm{~min}$, saturated at about
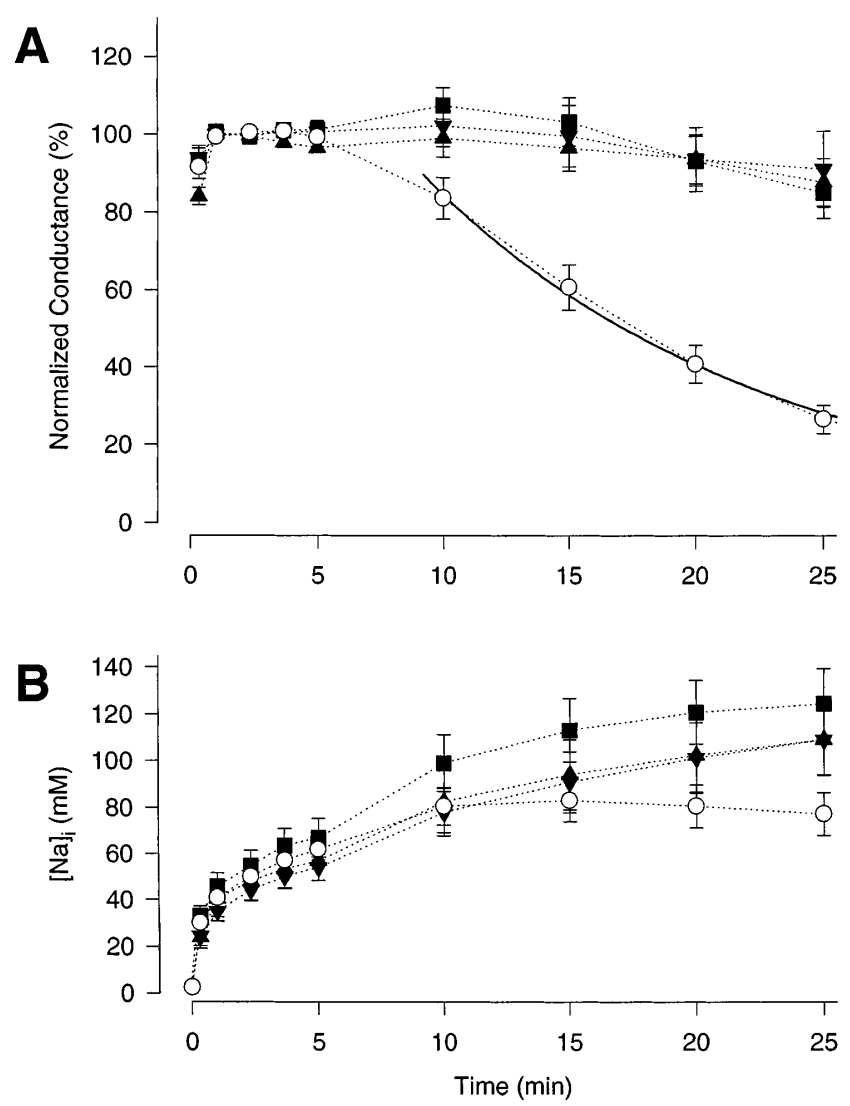

Figure 4. Time course of ENaC activity after a rapid increase in $\mathrm{Na}^{+}$ activity. Oocytes that had been incubated in $1 \mathrm{mM} \mathrm{Na}^{+}$MBS during the expression phase were voltage-clamped to $-100 \mathrm{mV}$, and the extracellular solution was switched to an oocyte Ringer solution of $95 \mathrm{mM}\left[\mathrm{Na}^{+}\right]_{\text {ext }}$ at time zero. $(A)$ Normalized conductance, and $(B)$ intracellular $\mathrm{Na}^{+}$activity $\left[\mathrm{Na}^{+}\right]_{\mathrm{i}}$ (see Methods) are shown for WT $\mathrm{ENaC}(\bigcirc)$ and the mutants $\alpha \beta R 564$ stop $\gamma(\boldsymbol{\square}), \alpha \beta \mathrm{P} 616 \mathrm{~L} \gamma(\mathbf{\Delta})$, and $\alpha \beta Y 618 \mathrm{~A} \gamma(\boldsymbol{\nabla})$. The solid line in $A$ represents a fit to a single exponential to the WT data. The rate and delay determined from the fit were $0.07 \mathrm{~min}^{-1}$ and $7.7 \mathrm{~min}$. The initial current was $5.4 \pm 0.5 \mu \mathrm{A}$ $(\mathrm{WT}, n=7), 5.9 \pm 0.7 \mu \mathrm{A}(\alpha \beta \mathrm{R} 564 \mathrm{stop} \gamma, n=7), 5.8 \pm 0.9 \mu \mathrm{A}$ $(\alpha \beta \mathrm{P} 616 \mathrm{~L} \gamma, n=6)$, and $4.7 \pm 0.5 \mu \mathrm{A}(\alpha \beta \mathrm{Y} 618 \mathrm{~A} \gamma, n=4)$. Oocytes had been injected with $1 \mathrm{ng} \alpha \beta \gamma \mathrm{cRNA} /$ oocyte for WT, and $0.3 \mathrm{ng}$ $\alpha \beta \gamma$ cRNA/oocyte in the case of the mutants. 
$10 \mathrm{~min}$ at $\sim 80 \mathrm{mM}$ for $\mathrm{WT}$, and further increased in the case of the mutant channels. As mentioned before, these values of $\left[\mathrm{Na}^{+}\right]_{\mathrm{i}}$ reflect $\left[\mathrm{Na}^{+}\right]_{\mathrm{i}}$ in a cytosolic compartment close to the plasma membrane, and not the overall $\left[\mathrm{Na}^{+}\right]_{\mathrm{i}}$ in the cytoplasm.

Assuming that the rundown of channel activity is due to feedback regulation of $\mathrm{ENaC}$ by $\left[\mathrm{Na}^{+}\right]_{i}$, the rate of this rundown should depend on the magnitude and the rate of $\mathrm{Na}^{+}$influx. The magnitude of $\mathrm{Na}^{+}$influx will in turn depend on the number of $\mathrm{ENaC}$ expressed at the cell surface. Accordingly, among oocytes expressing $\mathrm{ENaC}$, the ones with low levels of $\mathrm{ENaC}$ cell surface expression, will have a reduced influx of $\mathrm{Na}^{+}$, and the rise in $\left[\mathrm{Na}^{+}\right]_{i}$ will be slower. To test the assumption that the channel rundown is due to a feedback regulation, oocytes were injected with various concentrations of $\mathrm{ENaC}$ cRNAs to obtain different levels of channel expression, and the changes in channel activity were measured upon exposure to high extracellular $\mathrm{Na}^{+}$as described in experiments in Fig. 4. A representative experiment is shown in Fig. $5 \mathrm{~A}$, comparing the time course of changes in $\mathrm{I}_{\mathrm{Na}}$ in two oocytes expressing WT $\mathrm{ENaC}$, but with different magnitude of $\mathrm{I}_{\mathrm{Na}}$ expressed. The oocyte with the lower level of $\mathrm{ENaC}$ expression (initial $\mathrm{I}_{\mathrm{Na}}$ of 0.22 $\mu \mathrm{A})$ exhibits a slower rundown of channel activity, whereas for the oocyte with a high initial $\mathrm{I}_{\mathrm{Na}}\left(\mathrm{I}_{\mathrm{Na}}=1.94 \mu \mathrm{A}\right)$, the rundown was much faster. Similar experiments were performed comparing WT and $\alpha \beta$ R564stop $\gamma$ channels, and are shown in Fig. 5, $B$ and $C$. The rate of channel rundown after exposure to extracellular $\mathrm{Na}^{+}$was determined from fits to the time course of the change of $\mathrm{g}_{\mathrm{Na}}$. The rate constants of channel downregulation are plotted in Fig. $5 \mathrm{~B}$ vs. the initial $\mathrm{I}_{\mathrm{Na}}$, which is a measure of the $\mathrm{ENaC}$ expression level in individual oocytes. The rate of downregulation of $\mathrm{WT} \mathrm{ENaC}$ is directly related to the initial $\mathrm{I}_{\mathrm{Na}}$, i.e., the level of expression of $\mathrm{ENaC}$, suggesting that the channel rundown is linked to $\mathrm{Na}^{+}$influx into the cell. For the $\alpha \beta R 564$ stop $\gamma$ mutant, the rate of downregulation was very low, similar to the rate measured for WT for the lowest expression level, and remained independent of the level of initial $\mathrm{I}_{\mathrm{Na}}$ expression (Fig. 5 B). To further demonstrate the dependence of the rate of channel downregulation on $\left[\mathrm{Na}^{+}\right]_{\mathrm{i}},\left[\mathrm{Na}^{+}\right]_{\mathrm{i}}$ was calculated at 10, 15, and $20 \mathrm{~min}$, and the rate constants of downregulation are plotted vs. the mean of these $\left[\mathrm{Na}^{+}\right]_{\mathrm{i}}$ values (Fig. $5 C$ ). For WT channels, the rundown of channel activity is clearly dependent on $\left[\mathrm{Na}^{+}\right]_{\mathrm{i}}$ as shown by the increase of the rate constant of channel rundown at high $\left[\mathrm{Na}^{+}\right]_{i}$. For the Liddle mutants, channel rundown is slower and not significantly affected by intracellular $\mathrm{Na}^{+}$. These experiments support a feedback regulatory mechanism of ENaC by intracellular $\mathrm{Na}^{+}$ and the notion that the Liddle mutations result in a decrease in sensitivity to channel downregulation by intracellular $\mathrm{Na}^{+}$.

Previous work on $\mathrm{ENaC}$ feedback inhibition by intracellular $\mathrm{Na}^{+}$has pointed out the role of intracellular $\mathrm{Ca}^{2+}$ in this regulation (18). To test a possible involvement of intracellular $\mathrm{Ca}^{2+}$ in the rundown of WT ENaC that we observed upon $\mathrm{Na}^{+}$ influx into the oocyte (Figs. 4 and 5), WT ENaC-expressing oocytes were injected with $100 \mathrm{nl}$ of $2 \mathrm{mM}$ EGTA or $50 \mathrm{nl} 40$ mM BAPTA solution at least $2 \mathrm{~h}$ before the electrophysiological experiment to chelate intracellular calcium, and experiments were carried out in a calcium-free bath solution. Downregulation of ENaC activity in EGTA-injected oocytes was not different from oocytes in which calcium was not buffered (at $25 \mathrm{~min}, 22 \pm 2 \%$ of initial $\mathrm{g}_{\mathrm{Na}}, n=3$, in the presence of $\mathrm{Ca}^{2+}$; and $27 \pm 5 \%, n=4$, for EGTA-injected oocytes), and it was faster in BAPTA-injected oocytes (at $20 \mathrm{~min}, 46 \pm 2, n=3$ in
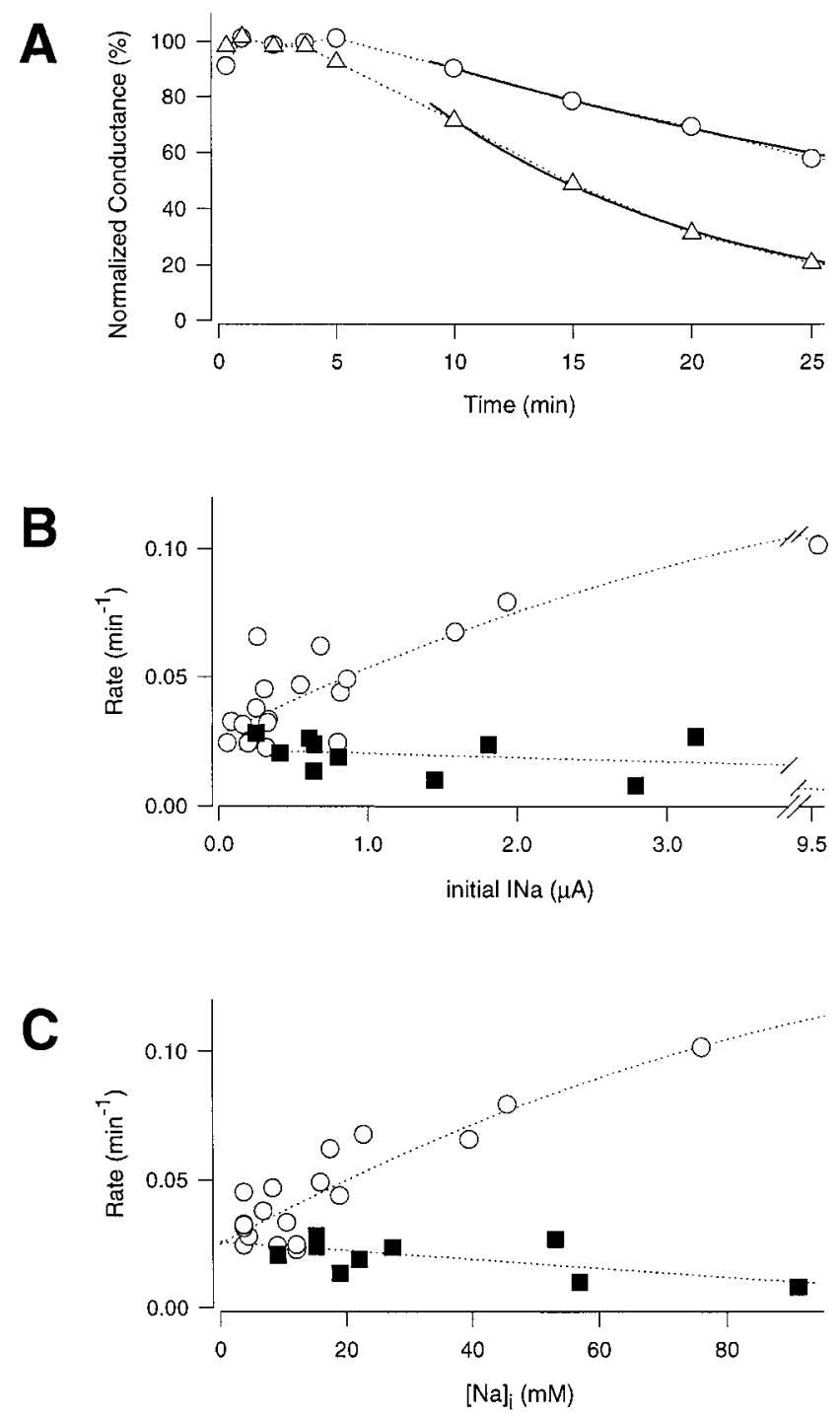

Figure 5. The rate of downregulation of ENaC activity depends on the $\mathrm{Na}^{+}$influx during the experiment. WT and mutant $\alpha \beta R 564$ stop $\gamma$ $\mathrm{ENaC}$ were expressed at various current levels by varying the amount of cRNA injected. $(A)$ Representative experiments, comparing channel downregulation in oocytes of low $(\bigcirc)$ or high $(\triangle)$ expression of WT ENaC. (O) The initial $\mathrm{I}_{\mathrm{Na}}$ was $0.22 \mu \mathrm{A},\left[\mathrm{Na}^{+}\right]_{\mathrm{i}}$ reached $5 \mathrm{mM}$ in the experiment (mean of values at 10,15, and $20 \mathrm{~min}$ ), and the single exponential fit yielded a rate of $0.0275 \mathrm{~min}^{-1}$ and a time delay of 6.3 min. $(\triangle)$ The corresponding values are $1.94 \mu \mathrm{A}, 46 \mathrm{mM}, 0.0793$ $\min ^{-1}$, and $5.8 \mathrm{~min}$. (B) The rate obtained from fits to the current decay in individual experiments of WT- $(\bigcirc)$ and $\alpha \beta R 564$ stop $\gamma(\mathbf{\square})$ expressing oocytes is plotted vs. the initial amiloride-sensitive current $\mathrm{I}_{\mathrm{Na}}$ as a measure of the $\mathrm{ENaC}$ expression level. Dotted lines represent a second order regression to the WT, and a first order regression to the $\alpha \beta$ R564stop $\gamma$ data. $(C)$ The rate obtained from fits to the current decay in individual experiments of WT- $(O)$ and $\alpha \beta R 564$ stop $\gamma(\boldsymbol{\square})-$ expressing oocytes is plotted vs. $\left[\mathrm{Na}^{+}\right]_{\mathrm{i}}$ reached in the experiment (mean of values at 10,15, and $20 \mathrm{~min}$ ). Dotted lines represent a second order regression to the WT, and a first order regression to the $\alpha \beta R 564$ stop $\gamma$ data.

the presence of $\mathrm{Ca}^{2+}$; and $24 \pm 6, n=3$, in BAPTA-injected oocytes). These experiments suggest that a rise in intracellular calcium is not essential for $\mathrm{Na}^{+}$-dependent regulation of $\mathrm{ENaC}$ activity. 


\section{Discussion}

This study identifies a novel molecular mechanism underlying the hyperactivity of $\mathrm{ENaC}$ resulting from mutations causing Liddle syndrome. Compared with $\mathrm{ENaC}$ wild type, channel mutants causing Liddle syndrome exhibit a higher average $\mathrm{Na}^{+}$current per channel and a higher number of ENaC molecules at the cell surface only under conditions of high intracellular $\mathrm{Na}^{+}$activity when WT ENaC activity is drastically downregulated. Under low $\left[\mathrm{Na}^{+}\right]_{\mathrm{i}}$ conditions, WT ENaC shows similar average $\mathrm{Na}^{+}$current per channel and channel density at the cell surface as Liddle mutants. The higher channel activity of Liddle mutants is due to a lower sensitivity to inhibition by intracellular $\mathrm{Na}^{+}$.

Hyperactivity of Liddle mutants. In experiments with high $\left[\mathrm{Na}^{+}\right]_{i}$, cell surface expression of mutants $\alpha \beta \mathrm{R} 564$ stop $\gamma$ and $\alpha \beta Y 618 \mathrm{~A} \gamma$ increased 1.8- and 2.4-fold over WT. The 1.2-fold increase in channel expression of the $\alpha \beta P 616 \mathrm{~A} \gamma$ mutant might be real, but did not reach statistical significance, probably due to the sensitivity of our binding assay. This result is consistent with previous observations showing a qualitatively higher immunofluorescence labeling of Liddle mutants at the apical plasma membrane of transiently transfected epithelial cells (12). In our study, however, the higher cell surface expression alone cannot account for the 4.8-6.8-fold increase in channel activity of Liddle mutants as measured by the amiloride-sensitive current, indicating that Liddle mutations also lead to an increase in the average $\mathrm{Na}^{+}$flux per channel present at the cell surface. As the single-channel conductance is not affected by Liddle mutations $(9,12)$, the increase in the ratio of current per channel reflects either an increase in channel open probability or a higher fraction of active vs. silent channels present at the cell surface.

A higher open probability for $\mathrm{ENaC}$ mutants relative to WT could not be demonstrated in a limited number of channel recordings (12). This is not entirely unexpected, since channel open probability of ENaC WT varies from $<0.1$ to $>0.9$, and demonstration of significant changes in channel gating between WT and Liddle mutants would require collection of a very large number of channel recordings (19). Such a study has not yet been performed, and therefore alterations in channel gating in Liddle mutants cannot be firmly excluded. Alternatively, a higher average current per mutant channel expressed at the cell surface could result from recruitment of a channel population present at the cell surface that is normally completely inactive or nonconductive. Evidences for a pool of inactive or weakly active channels is supported by our binding data. As mentioned previously, the average current per channel at the cell surface is around $2-6 \times 10^{-2} \mathrm{pA}$ under our recording conditions, i.e., at $-100 \mathrm{mV}$ holding potential. This average current per channel is approximately 10 -fold lower than that estimated from noise analysis in an amphibian kidney cell line (20). In addition, considering a single-channel current amplitude of $1 \mathrm{pA}$, as determined from patch clamp experiments for our recording conditions, the average open probability for all the channels detected at the cell surface would range from 0.02 to 0.06 , a value 10 times lower than the average open probability measured for active channels. Since in patch-clamp experiments, only active channels at the cell membrane are seen, whereas the binding experiment measures the total number of $\mathrm{ENaC}$ at the cell surface, our results are consistent with the notion that $\sim 90 \%$ of the $\mathrm{ENaC}$ at the cell surface are inac- tive and only $10 \%$ are active. Part of this pool of inactive channels at the cell surface may represent channels that are downregulated by intracellular $\mathrm{Na}^{+}$. It is conceivable that Liddle mutations may increase the fraction of active channels expressed at the cell surface as evidenced in our experiments by a higher current-per-channel ratio compared with WT ENaC.

The higher cell-surface expression of channel molecules of Liddle mutants can result from either an increase in the rate of insertion of $\mathrm{ENaC}$ into the plasma membrane, from a decrease in the rate of $\mathrm{ENaC}$ internalization, or from both. Our data showing similar rates of channel appearance at the cell surface after ENaC WT or mutant cRNA injection suggest that channel insertion and targeting at the plasma membrane is not directly affected by mutations in the PY motif (Fig. $1 A$ ). However, at times $8 \mathrm{~h}$ after cRNA injection in $\mathrm{Na}^{+}$-loaded oocytes, we cannot exclude that the rate of channel insertion at the plasma membrane might be different for WT ENaC and the Liddle mutant (Fig. $1 A$ ). The channel downregulation seen after an increase in $\left[\mathrm{Na}^{+}\right]_{\mathrm{i}}$ (Fig. 4) makes it seem more likely that the major mechanism underlying higher surface expression of ENaC Liddle mutants may be impaired channel internalization. Different mechanisms have been proposed for this channel retention at the plasma membrane. First, the PPPXYXXL motif, which is found in all $\mathrm{ENaC}$ subunits, contains two sequences that are associated with protein internalization, and might be required for clathrin-mediated endocytosis (12). This possibility is supported by a recent coexpression study of $\mathrm{ENaC}$ and a dominant-negative mutant of dynamin, a protein required for clathrin-mediated endocytosis which showed that currents were increased in WT, but not Liddle mutant-expressing oocytes (21). This result indicated that clathrin-mediated endocytosis is involved in $\mathrm{ENaC}$ internalization, and that the presence of PY motifs on $\mathrm{ENaC} \beta$ and $\gamma$ subunits is essential for this process. Second, Nedd4, a ubiquitin-ligase, binds to the PY motifs of $\beta$ and $\gamma \mathrm{ENaC}$. Mutation or deletion of the PY motifs disrupts this interaction and might lead to a reduction of ubiquitination and subsequent degradation. It has been shown that $\alpha$ and $\gamma$, but not $\beta$ subunits, are ubiquitinated in vivo, and that mutation of lysine residues, which are putative sites for ubiquitin attachment, leads to higher ENaC currents (22). Involvement of clathrin-mediated endocytosis and Nedd4induced ubiquitination in channel turnover at the cell surface are not mutually exclusive findings. The two mechanisms may occur sequentially during channel endocytosis and degradation, and may be triggered by an increase in intracellular $\mathrm{Na}^{+}$.

Feedback regulation of ENaC: role of intracellular $\mathrm{Na}^{+}$. Expression of the constitutively active ENaC in Xenopus oocytes leads to a rather unphysiological situation characterized by $\mathrm{Na}^{+}$entry into the cell through the expressed $\mathrm{ENaC}$ that exceeds the maximal rate of $\mathrm{Na}^{+}$extrusion by transporters like the $\mathrm{Na} / \mathrm{K}$-ATPase. This situation leads to a large increase in $\left[\mathrm{Na}^{+}\right]_{\mathrm{i}}$ and repression of ENaC activity at the cell surface. The general idea of feedback regulation of $\mathrm{ENaC}$ was first proposed by MacRobbie and Ussing, who noted that cells of the frog skin expressing an apical amiloride-sensitive $\mathrm{Na}$ channel did not swell as expected when $\mathrm{Na}^{+}$extrusion by the $\mathrm{Na}^{+} / \mathrm{K}^{+}$ ATPase was blocked $(2,23)$. They proposed that when intracellular $\left[\mathrm{Na}^{+}\right]_{\mathrm{i}}$ rises upon inhibition of the $\mathrm{Na} / \mathrm{K}$-ATPase, $\mathrm{Na}^{+}$ permeability of the apical membrane was downregulated to prevent cell $\mathrm{Na}^{+}$overload. The presence of this feedback regulation that inhibits the channel when $\mathrm{Na}^{+}$enters the cell has since been confirmed at the single channel level (17, 18, 24, 
25). It remains to be established whether this channel downregulation leads to channel closures and/or channel endocytosis. In a time scale of hours, our experiments suggest that both mechanisms are involved in channel downregulation, but the immediate effect of increasing $\left[\mathrm{Na}^{+}\right]_{\mathrm{i}}$ on channel activity over 10-20 min remains to be investigated. This feedback mechanism may serve to maintain intracellular ion homeostasis, and to allow homogenous reabsorption of $\mathrm{Na}^{+}$along the distal nephron.

$\mathrm{Na}^{+}$-dependent regulation of $\mathrm{ENaC}$ may require a sensor for $\mathrm{Na}^{+}$activity. This sensor could theoretically be either in $\mathrm{ENaC}$ itself or in another protein that would transmit the signal by direct interaction with $\mathrm{ENaC}$ (e.g., ENaC binding proteins carrying WW-domains), or translate it into another signal, e.g., a second messenger that would then act on $\mathrm{ENaC}$. Whatever this mechanism may be, at some point it must require the presence of an intact PY motif in both the $\beta$ and the $\gamma$ subunits. The PY motifs are not only required for internalization, but also for the regulation of the current passing through each channel. Analyzing the mediators of the $\mathrm{Na}^{+}-$ dependent regulation was not the focus of this study. However, the experiments done in BAPTA- and EGTA-injected oocytes seem to indicate that intracellular calcium activity does not play a direct role in channel feedback regulation. In mouse mandibular duct cells, involvement of $\mathrm{G}$ proteins in regulation of a highly selective epithelial $\mathrm{Na}$ channel by $\left[\mathrm{Na}^{+}\right]_{\mathrm{i}}$ has been demonstrated (26). Whether this channel is identical to $\mathrm{ENaC}$ has yet to be demonstrated, however, the data make $\mathrm{G}$ proteins possible candidates for mediators of $\mathrm{ENaC}$ regulation by $\left[\mathrm{Na}^{+}\right]_{\mathrm{i}}$.

Pathophysiological relevance. In several studies, intracellular $\mathrm{Na}^{+}$activities in the cortical collecting duct of rat or rabbit were measured by either electron microprobe analysis of freeze-dried cryosections or by a fluorescent dye technique (27-31). Under resting conditions $\left[\mathrm{Na}^{+}\right]_{\mathrm{i}}$ was 8 and $12 \mathrm{mmol} / \mathrm{kg}$ in the studies using the electron microprobe technique, and 23, 21 , and $22 \mathrm{mM}$ in the studies using a fluorescent dye. $\left[\mathrm{Na}^{+}\right]_{\mathrm{i}}$ increased up to 44 and $50 \mathrm{mM}$ after activation of second messenger pathways or pharmacological intervention. It is interesting to note that even though our $\left[\mathrm{Na}^{+}\right]_{\mathrm{i}}$ measurements reflect $\left[\mathrm{Na}^{+}\right]_{\mathrm{i}}$ close to the plasma membrane, $\left[\mathrm{Na}^{+}\right]_{\mathrm{i}}$ values found in cells of the cortical collecting duct are in the range of the apparent inhibitory constant of WT channels found in our experiments.

Feedback regulation of $\mathrm{ENaC}$ channel activity by intracellular $\mathrm{Na}^{+}$is likely to be an important cellular mechanism in controlling $\mathrm{Na}^{+}$reabsorption in the distal nephron in order to maintain $\mathrm{Na}^{+}$balance. This notion is supported by our finding that Liddle mutations causing hypertension result in a reduction of channel feedback regulation. It has been proposed that $\mathrm{ENaC}$ feedback inhibition may be involved in the rapid decline of channel activity during salt repletion of $\mathrm{Na}^{+}$-depleted rats (32). Consistent with this hypothesis is the observation that during salt repletion, the levels of plasma aldosterone and $\mathrm{ENaC}$ activity are not strictly correlated, suggesting that in addition to the effect of aldosterone, another factor downregulates the channel under these conditions. In Liddle patients lacking an efficient feedback inhibition of $\mathrm{ENaC}$, an elevated channel activity would persist despite a low plasma aldosterone level.

$\mathrm{ENaC}$ is expressed in different tissues, in particular in the lung, where it plays a critical role in $\mathrm{Na}^{+}$and fluid absorption at birth, and possibly in regulating the ionic composition of the airway surface liquid (32). We have shown in this paper that under conditions where $\mathrm{Na}^{+}$influx into the cell is limited and intracellular $\mathrm{Na}^{+}$activity is low enough not to trigger a negative feedback response, channel activity is similar for wild-type and Liddle mutants. It is conceivable that in some ENaCexpressing tissues in which the fluctuations of the extracellular $\mathrm{Na}^{+}$concentration are smaller than in the distal tubule, this regulatory feedback mechanism may not be active, or not essential for controlling $\mathrm{Na}^{+}$transport. It is expected that in such tissues (if they exist) Liddle mutations would have little effect on $\mathrm{Na}^{+}$transport. In this context it is interesting to note that Liddle patients do not show pulmonary symptoms, but it remains to be investigated whether $\mathrm{Na}^{+}$transport in respiratory epithelia of these patients is increased.

\section{Acknowledgments}

This work was supported by grants from the National Institutes of Health Consortium Project on Hypertension, the International Human Frontier Science Program, and from the Swiss National Foundation for Scientific Research (No. 31-49654.96 to L. Schild).

\section{References}

1. Rossier, B.C., C.M. Canessa, L. Schild, and J.-D. Horisberger. 1994. Epithelial sodium channels. Curr. Opin. Nephrol. Hypertens. 437:487-496.

2. Garty, H., and L.G. Palmer. 1997. Epithelial sodium channels: function, structure, and regulation. Physiol. Rev. 77:359-396.

3. Firsov, D., I. Gautschi, A.-M. Mérillat, B.C. Rossier, and L. Schild. 1998 The heterotetrameric architecture of the epithelial sodium channel $(\mathrm{ENaC})$. EMBO (Eur. Mol. Biol. Organ.) J. 15:101-108.

4. Canessa, C.M., L. Schild, G. Buell, B. Thorens, I. Gautschi, J.-D. Horisberger, and B.C. Rossier. 1994. Amiloride-sensitive epithelial $\mathrm{Na}^{+}$channel is made of three homologous subunits. Nature. 367:463-467.

5. Shimkets, R.A., D.G. Warnock, C.M. Bositis, C. Nelson-Williams, J.H Hansson, M. Schambelan, J.R. Gill, Jr., S. Ulick, R.V. Milora, J.W. Findling, et al. 1994. Liddle's syndrome: Heritable human hypertension caused by mutations in the $\beta$ subunit of the epithelial sodium channel. Cell. 79:407-414.

6. Hansson, J.H., C. Nelson-Williams, H. Suzuki, L. Schild, R. Shimkets, Y. Lu, C. Canessa, T. Iwasaki, B. Rossier, and R.P. Lifton. 1995. Hypertension caused by a truncated epithelial sodium channel gamma subunit: Genetic heterogeneity of Liddle syndrome. Nat. Genet. 11:76-82.

7. Hansson, J.H., L. Schild, Y. Lu, T.A. Wilson, I. Gautschi, R. Shimkets, C. Nelson-Williams, B.C. Rossier, and R.P. Lifton. 1995. A de novo missense mutation of the $\beta$ subunit of the epithelial sodium channel causes hypertension and Liddle syndrome, identifying a proline-rich segment critical for regulation of channel activity. Proc. Natl. Acad. Sci. USA. 92:11495-11499.

8. Tamura, H., L. Schild, N. Enomoto, N. Matsui, F. Marumo, B.C. Rossier, and S. Sasaki. 1996. Liddle disease caused by a missense mutation of $\beta$ subunit of the epithelial sodium channel gene. J. Clin. Invest. 97:1780-1784.

9. Schild, L., C.M. Canessa, R.A. Shimkets, I. Gautschi, R.P. Lifton, and B.C. Rossier. 1995. A mutation in the epithelial sodium channel causing Liddle disease increases channel activity in the Xenopus laevis oocyte expression system. Proc. Natl. Acad. Sci. USA 92:5699-5703.

10. Firsov, D., L. Schild, I. Gautschi, A.-M. Mérillat, E. Schneeberger, and B.C. Rossier. 1996. Cell surface expression of the epithelial $\mathrm{Na}$ channel and a mutant causing Liddle syndrome: A quantitative approach. Proc. Natl. Acad. Sci. USA. 93:15370-15375.

11. Schild, L., Y. Lu, I. Gautschi, E. Schneeberger, R.P. Lifton, and B.C. Rossier. 1996. Identification of a PY motif in the epithelial Na channel subunits as a target sequence for mutations causing channel activation found in Liddle syndrome. EMBO (Eur. Mol. Biol. Organ.) J. 15:2381-2387.

12. Snyder, P.M., M.P. Price, F.J. McDonald, C.M. Adams, K.A. Volk, B.G. Zeiher, J.B. Stokes, and M.J. Welsh. 1995. Mechanism by which Liddle's syndrome mutations increase activity of a human epithelial $\mathrm{Na}^{+}$channel. Cell. 83: 969-978.

13. Chen, H.I., and M. Sudol. 1995. The WW domain of Yes-associated protein binds a proline-rich ligand that differs from the consensus established for Src homology 3-binding modules. Proc. Natl. Acad. Sci. USA. 92:7819-7823.

14. Staub, O., S. Dho, P.C. Henry, J. Correa, T. Ishikawa, J. McGlade, and D. Rotin. 1996. WW domains of Nedd4 bind to the proline-rich PY motifs in the epithelial $\mathrm{Na}^{+}$channel deleted in Liddle's syndrome. EMBO (Eur. Mol. Biol. Organ.) J. 15:2371-2380. 
15. Schild, L., E. Schneeberger, I. Gautschi, and D. Firsov. 1997. Identification of Amino Acid Residues in the $\alpha, \beta, \gamma$ Subunits of the Epithelial Sodium Channel (ENaC) Involved in Amiloride Block and Ion Permeation. J. Gen. Physiol. 109:15-26.

16. Favre, I., E. Moczydlowski, and L. Schild. 1996. On the structural basis for ionic selectivity among $\mathrm{Na}^{+}, \mathrm{K}^{+}$, and $\mathrm{Ca}^{2+}$ in the voltage-gated sodium channel. Biophys. J. 71:3110-3125.

17. Frindt, G., R.B. Silver, E.E. Windhager, and L.G. Palmer. 1993. Feedback regulation of $\mathrm{Na}$ channels in rat CCT. II. Effects of inhibition of Na entry. Am. J. Physiol. 264:F565-F574.

18. Silver, R.B., G. Frindt, E.E. Windhager, and L.G. Palmer. 1993. Feedback regulation of Na channels in rat CCT. I. Effects of inhibition of Na pump. Am. J. Physiol. 264:F557-F564.

19. Palmer, L.G., and G. Frindt. 1996. Gating of Na channels in the rat cortical collecting tubule: Effects of voltage and membrane stretch. J. Gen. Physiol. 107:35-45.

20. Blazeryost, B.L., and S.I. Helman. 1997. The amiloride-sensitive epithelial Na channel-binding sites and channel densities. Am. J. Physiol. 41:C761C769.

21. Shimkets, R.A., R.P. Lifton, and C.M. Canessa. 1997. The activity of the epithelial sodium channel is regulated by clathrin-mediated endocytosis. J. Biol. Chem. 272:25537-25541.

22. Staub, O., I. Gautschi, T. Ishikawa, K. Breitschopf, A. Ciechanover, L. Schild, and D. Rotin. 1997. Regulation of stability and function of the epithelial $\mathrm{Na}$ channel (ENaC) by ubiquitination. EMBO (Eur. Mol. Biol. Organ.) J. 16: 6325-6336.

23. MacRobbie, E.A.C., and H.H. Ussing. 1961. Osmotic behaviour of the epithelial cells of frog skin. Acta Physiol. Scand. 53:348-365.
24. Frindt, G., L.G. Palmer, and E.E. Windhager. 1996. Feedback regulation of Na channels in rat CCT. IV. Mediation by activation of protein kinase C Am. J. Physiol. 270:F371-F376.

25. Frindt, G., R.B. Silver, E.E. Windhager, and L.G. Palmer. 1995. Feedback regulation of Na channels in rat CCT. III. Response to cAMP. Am. J. Physiol. 268:F480-F489.

26. Komwatana, P., A. Dinudom, J.A. Young, and D.I. Cook. 1996. Cytosolic $\mathrm{Na}^{+}$controls an epithelial $\mathrm{Na}^{+}$channel via the $\mathrm{G}_{\mathrm{o}}$ guanine nucleotidebinding regulatory protein. Proc. Natl. Acad. Sci. USA. 93:8107-8111.

27. Schlatter, E., S. Haxelmans, and I. Ankorina. 1996. Correlation between intracellular activities of $\mathrm{Ca}^{2+}$ and $\mathrm{Na}^{+}$in rat cortical collecting duct-a possible coupling mechanism between $\mathrm{Na}^{+}-\mathrm{K}^{+}$-ATPase and basolateral $\mathrm{K}^{+}$conductance. Kidney Blood Press. Res. 19:24-31.

28. Beck, F.X., A. Ohno, E. Muller, T. Seppi, and W. Pfaller. 1997. Inhibition of angiotensin-converting enzyme modulates structural and functional adaptation to loop diuretic-induced diuresis. Kidney Int. 51:36-43.

29. Stoos, B.A., N.H. Garcia, and J.L. Garvin. 1995. Nitric oxide inhibits sodium reabsorption in the isolated perfused cortical collecting duct. J. Am. Soc. Nephrol. 6:89-94.

30. Flemmer, A., A. Dorge, K. Thurau, and F.X. Beck. 1993. Transcellular sodium transport and basolateral rubidium uptake in the isolated perfused cortical collecting duct. Pflugers Arch. 424:250-254.

31. Breyer, M.D., and D. Fredin. 1996. Effect of vasopressin on intracellular $\mathrm{Na}^{+}$concentration in cortical collecting duct. Kidney Int. 57(Suppl.):57-61.

32. Hummler, E., P. Barker, J. Gatzy, F. Beermann, C. Verdumo, A Schmidt, R.C. Boucher, and B.C. Rossier. 1996. Early death due to defective neonatal lung liquid clearance in $\alpha \mathrm{ENaC}$-deficient mice. Nat. Genet. 12:325-328. 